e-ISSN: 2622-3597. Available online at https://jurnal.umj.ac.id/index.php/ELIF

Peer-review under responsibility of Muhammadiyah University of Jakarta, Indonesia

\title{
Systemic Functional Genre on Students' Reading Literacy
}

\author{
Lidiyatul Izzah 1), Muhamad Sofian Hadi'2) \\ 1), 2)Universitas Muhammadiyah Jakarta, South Tangerang, Banten, Indonesia \\ 1)izzahlidiyatul@gmail.com 2) M_Sofianhadi@yahoo.com
}

\begin{abstract}
In the context of higher education, IT's popularity and transparency has increased students' higher awareness of writing in different evolving forms. It is undeniable that publishing scientific research is now seen more as success determinant in academic careers. Along with this demand, students need to deepen their advanced literacy and academic language skills to achieve good scientific writing. The aim of the study was to investigate the impact of Systemic Functional Genre approach in students' reading literacy. A quantitative method of quasi-experimental design was carried out in this study. There were two groups involved: the experimental group (EG) and the control group (CG). During the implementation, both groups experienced in the different treatments. The population selected in this study was the second-semester learners of English Department, Muhammadiyah University of Jakarta. In selecting the sample, the researchers purposively choose two groups ( $n=60$ students). To collect the data, the researchers implemented a reading test. Based on the research finding, the study indicated that the SFG-based Approach had a significant positive impact on improving the students' reading literacy.
\end{abstract}

Keywords: functional grammar, genre approach, reading literacy, authentic text, systemic functional linguistic.

Citation APA Style: Izzah, L., \& Hadi, M. S. (2018). Systemic Functional Genre on Students' Reading Literacy. English Language in Focus (ELIF), 1(1), 35-44.

\section{INTRODUCTION}

I $\mathrm{n}$ the Fourth Industrial Revolution, the demand for having basic ICT skills becomes a vital emphasis, particularly in tertiary and postgraduate studies. It can be denied, publishing scientific research is now seen more as success determinant in academic careers. Students are required to reproduce knowledge as a tool for collecting data, sharpening critical thinking, and applying it to new education issue (Bazerman,
Bonini, \& Figueiredo, 2009). Together with the publishing demand, IT's popularity and transparency have increased students' higher awareness of writing in different evolving forms. To achieve good scientific writing, students need to deepen their advanced literacy and academic language skills. The most possible way to enrich their disciplinary languages is through critical reading. According to Bazerman, Bawarshi, \& Reiff (2013), critical reading in one's own 
and other's writing will help the reader to foster their metacognitive reflection, rhetorical awareness, and writing knowledge. As reading and writing are interconnected skills, they assumed that advanced writers likely have extensive experience as a reader. Considering its significance, so it is undoubted that a large number of researchers have devoted their time to study various aspects of the $\mathrm{L} 1$ and $\mathrm{L} 2$ reading (Carrell, 1988; Grabe, 1991; Mokhtari \& Sheorey, 2008).

Comprehension is the ultimate goal of reading, but it can be a slow and rigid process when a person is less skilled in L2 reading (Cammish, 2002). Reading a foreign language it doesn't only concern word interpretation, but also it is an intercultural exchange in all fields: social, professional, academic and personal. In today's reading theory, the paradigm has shifted the focus from purely cognitive onto contextual factors. Along with this change, the concept of reading has developed into reading literacy, that led to a shift in the communicative approach and authentic teaching material (Sulkunen, 2007). The development of communicative approach has so far highlighted the importance of reading as a high "communicative value" (Bernhardt \& Krashen, 2006). Likewise, teaching reading will be emphasized to the authentic materials and instruction (Byram \& Hu, 2017) and will be evaluated more on language understanding in general (Oakhill, Cain, \& Elbro, 2015, p. 1).

As the key to open the L2 community, authentic material is believed can help students in building their reading 'cultural framework' or schema theory (Mishan, 2004, p. 47). Several studies have shown that authentic texts are found to be relevant with the students (Sulkunen, 2007). It should be noted that the text must be distinctive and relevant to students, not just the original real-life text (Newmann, Marks, \& Gamoran, 1996). In classifying an effective authentic reading material, Cornu (1985, p. 198) suggesting a classification of texts according to their functional properties that appeal to a certain pragmatic or communicative function. As a result of this suggestion, the researcher decided to use the genre approach that focuses on communicative goals and text functions. In addition, it is beyond doubt that genre has survived as an effective form of language approach in schools (Rose \& Martin, 2012), universities (Berkenkotter, Bhatia, \& Gotti, 2012), and various professional backgrounds (Bhatia, 2002). Hence the researcher considered it necessary to investigate the impact of Systemic Functional Genre approach on students' reading literacy.

\section{Reading Literacy}

As explained in the introduction, the changes in the reading paradigm has shifted the reading focus from the pure cognitive to contextual aspects as well. Along with these changes, the reading concept has developed into literacy reading. It can be said reading theory does not only concentrate on decoding (D) and comprehension (C) (Adlof, Catts, \& Little, 2006; Grabe, 2009). They currently reflect rather the more social views of reading context. Several experts have classified reading theories so far, namely cognitive, sociocognitive, and 
sociocultural. For all that, rather similar but more emphasis on context has been presented in the sociocultural view (Scribner \& Cole, 1999; Vygotskil \& Cole, 1978). This view emphasizes that reading and writing should be treated as one unit of literacy since they are interrelated through their uses in society.

Literacy, as in reading literacy, is continually used for specific purposes in specific contexts (Scribner \& Cole, 1999) beyond the acts of reading and writing (Gee, 2000). The sociocultural view of reading further emphasizes that reading and writing are social practices, rather than being just situated in a static context of the reader's (writer's) community. These social practices, like all social practices and language use, is simultaneously shaped by culture (Bruner, 1986). Therefore, within the sociocultural view, the concept of literacy practices is proposed and defined as a general cultural approach in which people draw upon in literacy events (Barton \& Hamilton, 2000). A literacy event is something that can be observed but literacy practices are not observable since they involve people's values and attitudes, as well as their social relations.

Literacy practices are what people think about literacy, how people talk about it and make sense of it. However, this does not mean that literacy practices are basically personal. While individuals use their literacy practices, the practices connect people, exist in the relationship between people and involve general perceptions expressed in ideologies and social identities. The sociocultural view of literacy emphasizes that people have multiple literacies related to various fields of people's lives. Every literacy is related to certain social, cultural, historical and institutional contexts. Literacy activities originate from people's interests and needs, including social goals and cultural practices (Barton \& Hamilton, 2000).

PISA (2015) defined reading literacy as "understanding, using, reflecting on and engaging with written texts, in order to achieve one's goals, to develop one's knowledge and potential, and to participate in society". Reading literacy as "a functional use of acquired skill in a particular social context. Being literate means that one has to develop a broader set of skills, which activate the functional use of an acquired skill (e. g. language) in everyday life. Hence, reading literacy refers not only to mastering the reading skill, but also the ability to work with texts, communicate in writing, acquire and process information contained in texts." (Švrcková in Delgadova, 2015) .

\section{Systemic Functional Genre-Based Theories}

In the past decade, the genre has become one of the most important and influential concepts in language education. With the development of genre studies, communicative competence plays an important role in initiating the EFL learning discourse community into the target language. It is solely because of this competence is viewed as the ultimate goal in the process of learning genres in academic, institutional, and professional settings (Bhatia, 2004; Candlin, 2002; Deng, Chen, \& Zhang, 2014).

In the last 20 years, there have been so many publications, ingenious analysis, 
theoretical observations related to genres (Bazerman, 1988; Berkenkotter \& Huckin, 1995; Coe, Lingard, \& Teslenko, 2002; Swales, 2004). It has been widely agreed that genres should not be understood as templates but as parts that require constant production and improvisation. Then, over the last 15 years, in various different aspects and focuses, but with comprehensibility increased, genre analysts have been shifted from focusing on isolated phenomena to understanding how certain types of texts are formed by genres system. Genres have been described in terms of chains (Fairclough, 2003), colonies (Bhatia, 2002), repertoires (Devitt, 2008), sets and systems (Bazerman, 2003), and ecologies (Spinuzzi, 2004).

Genre theories include at least three different approaches: English for specific purposes (ESP), new literacy studies (NLS), and systemic functional linguistics, or the Sydney school (Correa \& Echeverri, 2017). (Hyland, 2002, p. 115 ) argued that SFL has been the most committed to use a "system language model" and a "meta-function grammar" to teach English language learners how to use academic genres. SFL is a school based on Hallidayan's functional linguistics (Halliday, 1978) and sociocultural learning theories (Vygotskil̆, 1978) which emphasizes the interactive and progressive models of various types in genres and the ways language is systematically related to context through lexico-grammatical and rhetorical features (Christie \& Martin as cited in Correa \& Echeverri, 2017).

Each genre has a generic structure that appropriates with its social purpose.
It contains different stages or "identifiable parts precisely because these steps enable the interactants to achieve the social purpose" (Painter, 2003, p. 170). In its classification, there are six types of texts identified by (Derewianka, 1990): narratives, recount, information reports, instruction, explanation, and expository texts.

\section{Teaching Learning Cycle}

The teaching-learning cycle is "an interactive process of contextualization, analysis, discussion, and joint negotiation of texts" (Hyland, 2002, p. 126). Its main goal is to promote students by providing models, well-defined instruction, and critical analyses of authors' and their own semiotic choices as they learn to interpret and produce academic texts in school" (Gebhard \& Harman, 2011, p. 49). As explained by Halliday (1978), it focuses on "the relationship between purpose, audience, and linguistic choice" (Yasuda, 2011, p. 112).

Related to implement the use of genre-based approaches, it is necessary to emphasize students to learn in detail the structure of various text types and linguistic features that are acceptable in their social and cultural contexts (Hyon, 1996). Referring to the Hyon's perspective, the role of the teacher is certainly very decisive and important. Because through the guided teaching approach, students are expected to be able to identify writing patterns and understand the intent used by the writer to communicate with readers. Besides, this approach allows students to learn the contents of the text by including an explanation based on their social language functions. 
Thus, to achieve that goal, it is important to describe the teaching-cycle procedures in the framework of pedagogical genre. These phases are negotiating field, deconstruction, joint construction, and independent construction (NSW, Department of School Education., 1992).

It should be noted that the study emphasizes the deconstruction phase, in which the teacher describes text, as an initial phase of the pedagogical genre process. The text selection is selected and prepared by the teacher. During the deconstruction phase, the teacher emphasizes on understanding structure and language included in the text. Students comprehend the text by highlighting aspects such as the social purpose of the genre, language features, and other aspects related to the context of cultural background (Ochoa \& Pérez, 2017). Similarly, Rose (2015, p. 7) explains that during the deconstruction phase, reading and discussing texts may help students to go beyond their independent reading skill. In this phase, teachers also can "guide student to identify and mark key information in each paragraph, building their (students) skills in recognizing and comprehending key information"

\section{RESEARCH METHODOLOGY}

$\mathrm{A}$ quantitative methods of the quasiexperimental design were carried out in this study. There were two groups involved: the experimental group (EG) and the control group (CG). During the implementation, both groups experienced in the different treatments. The population selected in this study was the second semester of English Study
Program, Educational Faculty, Muhammadiyah University Jakarta. In selecting the sample, the researchers purposively choose two classes (60 students), e.g. AING class as the experimental group and BING class as the control group.

To collect the data, the researchers implemented pre-test and post-test. The pre-test and post-test were employed to determine whether Systemic Functional Genre-based approach become an effective approach to improve students' reading literacy in authentic texts. Before determining the hypothesis of the study, the Kolmogorov Smirnov test (used in a normal distribution) and the Levene test (used in homogeneity of variance test) was conducted. Finally, to determine the significant difference between the two groups' means, the t-test was selected.

\section{FINDING AND DISCUSSION}

$\triangle \begin{aligned} & \mathrm{S} \text { explained earlier, the } \\ & \text { Kolmogorov Smirnov test was }\end{aligned}$ used to check whether the posttest scores of both groups were normally distributed. The result showed a follow.

Table 1. Normality test

\begin{tabular}{|c|c|c|c|c|c|c|}
\hline & \multicolumn{3}{|c|}{ Kolmogorov-Smirnov $^{\mathbf{a}}$} & \multicolumn{3}{|c|}{ Shapiro-Wilk } \\
\hline & Statistic & $\mathrm{df}$ & Sig. & Statistic & $\mathrm{df}$ & Sig. \\
\hline Score & .083 & 60 & $.200^{*}$ & .974 & 60 & .230 \\
\hline
\end{tabular}

The significance value of both groups was (0.230) higher than the significant level (0.05). Obviously, the scores of both groups were normally distributed. The Levene test was then used to analyze the homogeneity of 
variance scores of both groups. The Levene test result showed as follow.

Table 2. Homogeneity of Variances Test

\begin{tabular}{cccc}
$\begin{array}{c}\text { Levene } \\
\text { Statistic }\end{array}$ & df1 & df2 & Sig. \\
\hline .933 & 7 & 21 & .502 \\
\hline
\end{tabular}

From table 2 it can be seen the value of homogeneity in post-test was 0.502 with significant 0.05 . It means the data of post-test was homogeneous because the value of post-test was bigger than the significant $(0.502>0.05)$. Therefore, it can be concluded that the control and experimental groups variances are homogeneous or equal.

Table 3. Group Statistics

\begin{tabular}{cccccc}
\hline \multirow{4}{*}{ Post_Test } & Class & $\mathrm{N}$ & Mean & Std. Deviation & $\begin{array}{c}\text { Std. Error } \\
\text { Mean }\end{array}$ \\
\cline { 2 - 6 } & Experiment & 30 & 83.6667 & 10.41661 & 1.90180 \\
& Control & 30 & 62.6667 & 11.04328 & 2.01622 \\
\hline
\end{tabular}

From that table, the researcher got to conclude that the experimental group has 30 students with a mean of post-test score 83.6667, and the standard deviation is 10.41661. Whereas the statistic of the control group showed that also has 30 students, mean of the posttest score is 62.6667 , and the standard deviation is 11.04328. The standard deviation of the experimental group is lower than control group
$(10.41661<11.04328)$ so that a variation distance of the control group data is larger than the experimental group has. Lastly, the t-test was conducted to investigate whether there were significant differences between the experimental and the control group. The hypotheses set out in this analysis were in the form of a null hypothesis and alternative hypothesis.

Table 4.Independent Sample Test

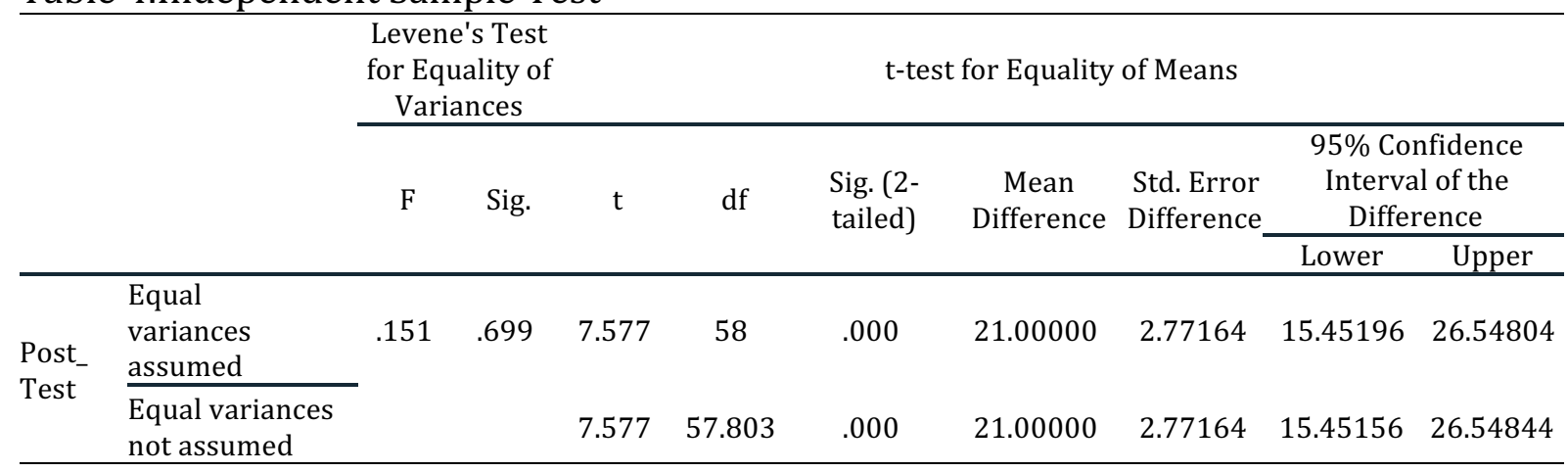

The result showed that the significance value of both groups is lower than the significance level $(0,000<0.05)$. Therefore, the null hypothesis (H0) was rejected. In other words, the averages of both groups were significantly different. It means that the treatment which was implemented in the experimental group significantly improved the students' reading literacy skill.

\section{CONCLUSION}

Based on the research finding, the study indicated that the SFG-based Approach 
was an effective approach in improving the students' reading literacy. The result from t-test shows that there is a significant difference between the means of the experimental group and those who were in the control group. The result finds out that the significant value is bigger than $r$ critical. Therefore, the null hypothesis is rejected It means that the treatment that was given to the experimental group is significant to improve the students' reading literacy.

\section{REFERENCES}

Adlof, S. M., Catts, H. W., \& Little, T. D. (2006). Should the Simple View of Reading Include a Fluency Component? Reading and Writing, 19(9), 933-958. https://doi.org/10.1007/s11145006-9024-z

Barton, D., \& Hamilton, M. (2000). Literacy Practices. In D. Barton, M. Hamilton, \& R. Ivanič (Eds.), Situated Literacies: Reading and Writing in Context (pp. 7-15). https://doi.org/10.3368/aoj.57.1.14 4

Bazerman, C., Bonini, A., \& Figueiredo, D. (Eds). (2009). Genre in a Changing World. Indiana: ParlorPress.

Bazerman, C, Bawarshi, A., \& Reiff, M. J. (2013). Series Editors' Preface. In A. S. Horning \& E. W. Kraemer (Eds.), Reconnecting Reading and Writing (p. 325). Anderson SC: Parlor Press.

Bazerman, Charles. (1988). Shaping Written Knowledge: The Genre and Activity of the Experimental Article in Science (Rhetoric of the Human Services). Madison: University of Wisconsin Press.

Bazerman, Charles. (2003). Speech Acts, Genres, and Activity Systems: How Texts Organize Activity and People. In C. Bazerman \& P. A. Prior (Eds.),
What Writing Does and How It Does It: An Introduction to Analyzing Texts and Textual Practices (pp. 309339).

9gi5yhttps://doi.org/10.4324/9781 410609526

Berkenkotter, C., Bhatia, V. K., \& Gotti, M. (Eds.). (2012). Insights into Academic Genres. Bern: Peter Lang.

Berkenkotter, C., \& Huckin, T. N. (1995). Genre Knowledge in Disciplinary Communication: Cognition, Culture, Power. New Jersey: NJ Lawrence Erlbaum.

https://doi.org/10.1109/TPC.1996. 503277

Bernhardt, E. B., \& Krashen, S. D. (2006). Second Language Acquisition and Second Language Learning. The Modern Language Journal. 73(4), 483.

https://doi.org/10.2307/326882

Bhatia, V. (2002). Applied Genre Analysis Analytical Advances and Pedagogical Procedures. In A. M. Johns (Ed.), Genre in the Classroom: Multiple Perspectives (pp. 279-284). Mahwah, NJ: Lawrence Erlbaum Associates.

Bhatia, V. K. (2004). Worlds of Written Discourse: A Genre-Based View. London: Continum.

Bruner, J. S. (1986). Actual Minds, Possible Worlds. Cambridge, MA, US: Harvard University Press.

Byram, M., \& Hu, A. (Eds.). (2017). Routledge Encyclopedia of Language Teaching and Learning. New York: Routledge.

Cammish, N. K. (2002). Through a Glass Darkly: Problems of Studying at Advanced Level Through the Medium of English. In D. McNamara \& R. J. Harris (Eds.), Overseas Students in Higher Education: Issues in Teaching and Learning (pp. 128143). New York: Routledge. 
Candlin, C. N. (Ed.). (2002). Research and Practice in Professional Discourse. Hongkong: City University of Hong Kong.

Carrell, P. L. (1988). SLA and Classroom Instruction: Reading. Annual Review of Applied Linguistics. https://doi.org/10.1017/s0267190 $50000091 x$

Coe, R. M., Lingard, L., \& Teslenko, T. (2002). The Rhetoric and Ideology of Genre: Strategies for Stability and Change. New York: Hampton Press.

Cornu, A-M., Vanparijs, J., Delahaye, M. and Baten, L. (eds) . (1985). Beads Or Bracelet?: How Do We Approach LSP : Selected Papers from the Fifth European Symposium on LSP. Leuven

Correa, D., \& Echeverri, S. (2017). Using a Systemic Functional Genre-Based Approach to Promote a Situated View of Academic Writing Among EFL Pre-service Teachers. HOW, 24(1), 44-62. https://doi.org/10.19183/how.24.1. 303

Delgadova, E. (2015). Reading Literacy as One of the Most Significant Academic Competencies for the University Students. Procedia Social and Behavioral Sciences, 178, 48-53.

https://doi.org/10.1016/J.SBSPRO.2 015.03.145

Deng, L., Chen, Q., \& Zhang, Y. (2014). Developing EFL Learners' Generic Competence in Reading and Writing: A Process Genre Approach. In Developing Chinese EFL Learners' Generic Competence. New York: SpringlerVerlag Berlin Heidelberg. https://doi.org/10.1007/978-3642-54845-1_4

Derewianka, B. (1990). Exploring How Texts Work. Canada: Primary English Teaching association.

Devitt, A. J. (2008). Writing Genres.
Carbondale: Southern Illinois University Press.

Fairclough, N. (2003). Analysing Discourse: Textual Analysis for Social Research. London: Routledge.

Gee, J. P. (2000). Discourse and Sociocultural Studies in Reading Semantic Scholar. Reading Online, 4(3), 1-10. https://doi.org/10.4324/97814106 $05023 \mathrm{ka}$

Grabe, W. (1991). Current Developments in Second Language Reading Research. TESOL Quarterly, 25(3), 375-406. https://doi.org/10.2307/3586977

Grabe, W. (2009). Reading in a Second Language: Moving from Theory to Practice. Cambridge: Cambridge University Press.

Hyland, K

(2002).

Genre: Language, context and litera

y. Annual Review of Applied Linguistics, 22, 113-135. https://doi.org/10.1017/S0267190 502000065

Hyon, S. (1996). Genre in Three Traditions: Implications for ESL. TESOL Quarterly, 30(4), 693-722. https://doi.org/10.2307/3587930

Mishan, F. (2004). Designing Authenticity into Language Learning Materials. USA: Intellect Ltd.

Mokhtari, K., \& Sheorey, R. (2008). Differing Perceptions of Reading Strategy Use Between Native and Non-Native College Students. In K. Mokhtari \& R. Sheorey (Eds.), Reading Strategies of First and Second-Language Learners: See How They Read (pp. 131-141). Norwood, MA: Christopher-Gordon Publishers.

Newmann, F. M., Marks, H. M., \& Gamoran, A. (1996). Authentic Pedagogy and Student Performance. American Journal of Education, 104(4), 
https://doi.org/10.1086/444136

NSW Department School. (1992). The Action Pack: Activities for Teaching Factual Writing. Erskineville N.S.W.: Dept. of School Education, Metropolitan East Disadvantaged Schools Program.

Oakhill, J., Cain, K., \& Elbro, C. (2015). Understanding and Teaching Reading Comprehension. Abington, UK: Routledge.

Ochoa, Y. D. C. A., \& Pérez, L. M. F. (2017). Genre Based Approach Pedagogy to Improve reading Comprehension in 8th Grade Students. Retrieved from http://manglar.uninorte.edu.co/bits tream/handle/10584/7492/129975 .pdf? sequence $=1$ \&isAllowed $=y$

Painter, C. (2003). Understanding genre and register: Implications for language teaching. In A. Burns \& $\mathrm{C}$. Coffin (Eds.), Analysing English in a Global Context: A Reader (pp. 167180). London: Routledge in association with Macquarie University and the Open University.

PISA. (2015). Draft Reading Literacy Framework. Retrieved from https://www.oecd.org/pisa/pisapro ducts/Draft PISA 2015 Reading Framework .pdf

Rose, D., \& Martin, J. R. (2012). Learning to Write/Reading to Learn; Genre, Knowledge and Pedagogy in the Sydney School. London, Oakville, CT :
Equinox Pub

Scribner, S., \& Cole, M. (1999). The Psychology of Literacy. Cambridge: Harvard University Press.

Spinuzzi, C. (2004). Four Ways to Investigate Assemblages of Texts: Genre Sets, Systems, Repertoires, and Ecologies. Sigdoc '04, 110-116. https://doi.org/10.1145/1026533.1 026560

Sulkunen, S. (2007). Text Authenticity in International Reading Literacy Assessment Focusing on PISA 2000 (University of Jyväskylä).

Swales, J. M. (2004). Research Genres: Explorations and Applications. Cambridge: Cambridge University Press.

Vygotskiı̌, L. S. (1978). Mind in society: the development of higher psychological processes. Harvard University Press.

Yasuda, S. (2011). Genre-Based Tasks in Foreign Language Writing: Developing Writers' Genre Awareness, Linguistic Knowledge, and Writing Competence. Journal of Second Language Writing, 20(2), 111-133.

https://doi.org/10.1016/J.JSLW.201 1.03.001 
English Langouage in Focus (ELIF), 1 (1), 35-44. https://jurnal.umj.ac.id/index.php/ELIF 